\title{
Indigenous Knowledge in Post-Secondary Educators' Practices: Nourishing the Learning Spirit
}

Jonathan Anuik

University of Alberta

Carmen L. Gillies

University of Saskatchewan

\begin{abstract}
From 2006 to 2009, Indigenous Elders and scholars shared their insights in the Comprehending and Nourishing the Learning Spirit Animation Theme Bundle of the Aboriginal Learning Knowledge Centre (ABLKC). The ABLKC was an applied research, knowledge exchange, and monitoring program with a mandate to advance Aboriginal education in Canada. One of the six bundles, Nourishing the Learning Spirit, was led by Mi'kmaw education scholar and Academic Director of the Aboriginal Education Research Centre at the University of Saskatchewan, Dr. Marie Battiste. In this paper, the authors discuss how they applied knowledge gained in the Nourishing the Learning Spirit Animation Theme Bundle to their post-secondary classroom practice. The authors argue that teachers are better able to nourish the learning spirit of students when they understand themselves as lifelong learners, validate and learn from their students, and use holistic teaching pedagogies.
\end{abstract}

\section{RÉSUMÉ}

De 2006 à 2009, les aînés autochtones et les pédagogues ont partagé leur compréhension de l'esprit de l'apprentissage dans un ensemble de trousses d'animation (Comprehending and Nourishing the Learning Spirit Animation Theme Bundle). L'une des six trousses, Nourishing the Learning Spirit, a été chapeautée par la directrice de l'Aboriginal Education Research Centre 
(ABLKC) à l'Université de la Saskatchewan, $\mathrm{D}^{\text {re }}$ Marie Battiste, chercheure en éducation d'origine micmaque (mi' kmaq). L'ABLKC était un programme de recherche appliquée, d'échange d'idées et de contrôle, ayant un mandat de reportage visant l'avancement de l'éducation autochtone au Canada. Dans le présent document, les chercheurs discutent des connaissances acquises au cours de l'implantation de la trousse Nourishing the Learning Spirit dans leur salle de classe postsecondaire. Ils affirment que les professeurs peuvent nourrir l'esprit d'apprentissage de leurs élèves quand ils se voient eux-mêmes comme apprenants perpétuels, valorisent et apprennent de leurs élèves, et utilisent des pédagogies d'enseignement holistiques.

Certain situations enable the heart and the brain to collaborate but where there is a disturbance between the two, learning cannot happen. (Kelly as cited in Anuik \& Battiste, 2008, p. 14)

This epigraph suggests how learning may be perceived and transformed in post-secondary settings. It was stated at the May 2007 Banff Dialogue convened by Dr. Marie Battiste, Mi'kmaw Professor of Educational Foundations and Academic Director of the Aboriginal Education Research Centre at the University of Saskatchewan and former codirector of the Aboriginal Learning Knowledge Centre (ABLKC). The Banff Dialogue was part of the knowledge exchange activities of the ABLKC, a three-year project completed in 2009 with a mandate for knowledge exchange, applied research, and monitoring and reporting in Aboriginal lifelong learning (Canadian Council on Learning, 2006). The epigraph braids the objectives of modern learning with a holistic interpretation of the capacity of humans to learn.

In this paper, Jon, a non-Aboriginal scholar of Métis lifelong learning, and Carmen, a Métis-scholar of anti-racism education, describe how Indigenous knowledge (IK) acquired from working with the ABLKC shaped Jon's instruction of Inquiry 1010 and 1030 at Lakehead University Orillia campus and Carmen's instruction of First Nations and Cross-Cultural Education at the College of Education, University of Saskatchewan. Because we do not wish to perpetuate a pan-Indigenous approach to pedagogy, we identify specific nations of Indigenous peoples whenever possible. We use the term Indigenous Knowledge to refer to the foundational and practical knowledge held by Indigenous peoples globally, and the term Aboriginal to refer to the First Nation, Métis, and Inuit people in Canada.

We argue that all learners have the ability to inquire and learn, but the task of the teacher is to establish an environment that evokes an outpouring of critical thought (brain) and passion (heart) (Cajete, 2000) as a means to overcome fear (blockage and resistance) (George, 2010). Thus, we have applied Indigenous teachings to assist in the collaboration of the heart and brain, knowledge that has been largely excluded, until recently, from Canadian education systems. Although we draw insights from gatherings such as the Banff Dialogue - a forum for the sharing of IK as it pertains to learning - and Indigenous scholars, we are not holders of IK. Instead, we attempt in this paper to make meaning from perspectives shared during the ABLKC project. We reflect on the academic year (2009-2010) that followed our research work for the ABLKC with an eye to uncovering promising practices, based on our ongoing conversations about the application of IK to post-secondary educators' practices. 
We agree on the requirement for teachers to animate the principle of holism, engaging mentally, emotionally, spiritually, and physically with all topics covered in class. Scholars have argued to include IK in post-secondary institutions' curriculum, but few scholars have addressed how teachers can effect changes in their practices to centre Indigenous knowledge and experiences (Kovach, 2010). Reflecting on her years as a literacy teacher, Ningwakwe George, Anishinabe, advised teachers, "Listen with your eyes, ears, heart, and spirit" (as cited in Anuik \& Battiste, 2008, p. 14). Wiebe and Guiney Yallop (2010) also suggested, "In schools, hearts need caring, hearts need our attention, our investment and time" (p. 179). As teachers and lifelong learners, we believe emotional and spiritual growth is a requisite for learning. However, that point is often not recognized in the educational system:

We are embodied to learn, especially to fulfill our purpose, the Creator's law teaches us. The focus on academic and physical competencies means that our current system fulfills only half of the needs of learners; this imbalance knocks many learners on their backs. And when I think of the education system, I think we are doing great harm to children by teaching them that the only things worth knowing are inherited from somewhere else rather than what is learned in the chronology of the moment. (George as cited in Anuik \& Battiste, 2008, p. 15)

This learning with only half of the body - mentally and, occasionally, physically impedes learners from achieving their full capacity and purpose.

According to many Indigenous teachings, the Creator has given each learner gifts to fulfill a unique purpose. Salteaux Elder Danny Musqua stated that connecting to the Creator's gifts to achieve purpose requires "not only the use of the mind, but also the use of the heart, body, and spirit of the individual" (as cited in Knight, 2007, p. 9). Each learner's purpose is carried by "a spirit and [is on] a journey to carry out" the Creator's agenda (Musqua as cited in Anuik \& Battiste, 2008, p. 13). Teachers and administrators in Canadian schools and provincial and territorial ministries of education, however, often concentrate exclusively on proficiency in mental competencies.

\section{MODERN EDUCATION}

Battiste (1986) stated: "Certain myths have disguised the functions and value of literacy in society. Viewed as the benign liberator of the mind, literacy is perceived to be the modernizing agent of society and an economic commodity necessary for national development" (p. 23). Battiste's comprehension of modern literacy dovetails with historical understandings of education. In Canada, Methodist clergyman Egerton Ryerson believed all children needed a common set of skills: English literacy and numeracy as a means to become citizens of Canada (Curtis, 1987, 1992). These skills were integral to the expansion and maintenance of imperialism and colonialism in Canada. From the early 180os, schoolhouses were the sites where clergy and lay teachers shared lessons in literacy, assuming that all students gravitated to what Monture (1995) called "the truth" (pp. 94, 114-115, 117). In missionary, Indian Residential, and public and Roman Catholic separate schools, students "received explicit instruction in the ideology of imperialism" (Francis, 1997, p. 53) that included the disruption and devaluing of intergenerational IK transmission in In- 
digenous communities. To describe historical and current educational theory and practice in colonized territories, Battiste (2000) coined the term cognitive imperialism or "the imposition of one worldview on a people who have an alternative worldview, with the implication that the imposed worldview is superior to the alternative worldview" (pp. 192-193).

In many ways, teachers continue to impart to students the "inevitability of imitating Eurocentric modes of thought" (Henderson, 2000, p. 256). As Willinsky (1998) articulated, "Given the enormity of imperialism's educational project and its relatively recent demise, it seems only reasonable that this project would live on, for many of us, as an unconscious aspect of our education" (p. 3). As Battiste taught, everyone has been marinated in Eurocentric thought, and "every researcher/student has been a victim and beneficiary of the same educational system" (as cited in Battiste, Anuik, \& Gillies, 2009), though such outcomes vary greatly according to racial classifications and ancestry. Nevertheless, in the universities, Battiste (2005) argued that Aboriginal students "can access what is available, but they cannot change the existing knowledge base" (p. 224). Aboriginal families in Canada have at times wanted their children to receive "a white or Western-based style of instruction" (Anuik, 2010, p. 85; see also Adams, 1972) to help their children succeed and survive in modern society (Anuik, 2010). Schools, however, have responded with liberal, modal adjustments to support Aboriginal learners rather than with vigorous academic pedagogy and high expectations of students (Battiste, 2000; see also Anuik, 2009). In addition, this modern knowledge does not coexist in the classroom "with the knowledge of how to achieve a decolonized education" (Battiste, Anuik, \& Gillies, 2009). The response to this criticism is that "all must become critical learners and healers in a wounded space" (Battiste, Anuik, \& Gillies, 2009). Part of this healing involves honouring and practising Indigenous teachings that stimulate the heart as well as the brain to collaborate in post-secondary education. However, the challenges are formidable, especially because the objectives set for learners and teachers were established long before either party entered post-secondary institutions.

\section{NOURISHING THE LEARNING SPIRIT}

The ABLKC drew on foundational expertise through partnerships with the Congress of Aboriginal Peoples, the Inuit Tapiriit Kanatami, the Métis National Council, the Assembly of First Nations, and the Native Women's Association of Canada, the major political bodies that represent Indigenous peoples in Canada. In addition, we sought guidance from staff, teachers, principals, superintendents, and directors, as well as Elders, resource people, and "Old People" or "Old Ones" from the over 600 First Nation, Métis, and Inuit communities in Canada.

The work of the ABLKC was divided into six Animation Theme Bundles (ATB). Battiste and her collaborators explained the need for the Nourishing the Learning Spirit ATB:

Little is known about the learning journey that each person travels to arrive comfortably at their own awareness of their gifts, capacities, and strengths, which is broadly the result of their learning spirit being invigorated, challenged, motivated, or nourished. How that learning spirit evolves in a lifetime to create a learning journey is also less well known. (adapted from the Canadian Council on Learning, 2006) 
Early on a tension emerged. The Canadian Council on Learning (CCL) created the $\mathrm{ABLKC}$ to serve as a forum for knowledge exchange, applied research, and monitoring and reporting on learning (n.d.). However, CCL personnel focused initially on ways to draw Aboriginal learners into existing educational systems and expected lead researchers to devise projects dedicated to small adaptations to support learning as opposed to transformation or decolonization in pedagogy and practices. Rather than take a deficit approach to Aboriginal learners, the ABLKC sought to invest in what Smith (1999) had described as a "long-term process involving the bureaucratic, cultural, linguistic and psychological divesting of colonial power" (p. 98). The CCL wanted the ABLKC lead researchers and stakeholders in communities to devise practices directed toward the acceptance and acquisition of English and French literacy, numeracy, and citizenship skills. Instead, it was the goal of researchers involved in the ABLKC to braid modern education with IK (George, 2010; Malreddy Kumar, 2009). The researchers decided to reframe the task as how to animate Aboriginal paradigms of learning in diverse educational contexts throughout Canada (Anuik \& Battiste, 2008). In other words, Battiste and the researchers she supervised wanted to contribute to the decolonization of pedagogy by understanding how IK could enable success in conventional measurements such as attendance, grades, and graduation rates (Battiste, 2007).

\section{Banff Dialogue}

In spring 2007, Battiste convened a dialogue with Aboriginal scholars and practitioners involved with lifelong learning in Aboriginal communities and mainstream educational institutions to convey to the CCL how Aboriginal learners' aspirations for lifelong learning differ from contemporary understandings of the objectives of learning. The dialogue occurred on May 14-16, 2007, at Banff, Alberta, in traditional Blackfoot Territory. Leroy Little Bear, Blackfoot and Professor of Native American Studies at the University of Lethbridge, moderated the discussion. Little Bear encouraged the participants to let the dialogue be generative; that is, the themes emerged from the participants. He then synthesized the discussions at the end of each session. As a result, participants were free to share their thoughts without being restricted by a preconceived agenda. Everyone in attendance at the dialogue shared Indigenous understandings of pedagogy. Although much of the work with the Nourishing the Learning Spirit ATB influenced how we understand and practise our pedagogy, the teachings shared at the dialogue also led to significant transformations in teaching philosophies and practices.

\section{INQUIRY 1010 AND 1030}

Before discussing the Inquiry courses at Lakehead University's Orillia campus, we will identify the insights gleaned from the ABLKC knowledge exchange activities that in Jon's opinion affected his role as a teacher and learner in the two courses. George (2010) proposed considerations for practitioners in adult literacy learning in response to problems identified by Battiste and the lead researchers. More specifically in terms of spirituality, George (2010), drawing from literature on educational policy and scientific experiments and treatises on spirituality, individualized learner outcomes in relationship to collective aspirations in learning. She concluded: 
1. The Aboriginal worldview is holistic - we are Spirit, Heart, Mind, and Body

2. We are a part of Creation; we are not separate from it

3. We all have a purpose for being here and we have gifts from the Creator that are to be used for fulfilling that purpose and

4. Everything is/has Spirit/Energy. We need to be mindful of our feelings, thoughts, words, and actions. What we put out there affects everybody and everything else. (as cited in Anuik, Battiste, \& George, 2008, pp. 3-4)

Ball and Pence (2006) contributed to George's understanding of spirituality in learning through a paradigm of generative knowledge for early childhood education that can be applied to all levels of education. In this paradigm, knowledge is co-constructed in a culturally safe space and put into practice through "reciprocal teaching and learning; respect for knowledge 'all ways' [and 'always']; and unlearning of expert presumption of universal validity of knowledge and expertise” (p. 83).

Wiebe and Guiney Yallop (2010) agreed with George (2010) and Ball and Pence (2006), urging educators "to open safe spaces for students to feel like they really belong" (p. 280). Professors need to break away from the current system of education that positions "students ... as non-knowers [without] ... privilege to explore, create, and play with the possibilities of learning" (Wiebe \& Guiney Yallop, 2010, p. 191). George (2010) and Ball and Pence (2006) depicted the foundations and practices required to build on the expectation of proficiency in the brain, but they also opened the door in conventional classrooms to a pedagogy of the heart (Freire, 1998), which in turn stimulates the heart and brain to collaborate in the pursuit of inquiry.

In August 2009 - after the completion of the ABLKC project - Jon was hired at Lakehead University's Orillia campus in Orillia, Ontario. This campus opened in 2006, and among its many educational innovations are two courses, required as part of the interdisciplinary Honours Bachelor of Arts and Science and Bachelor of Education degrees: Inquiry 1010 (Foundations of Inquiry) and 1030 (Applications of Inquiry). In Inquiry, instructors expect students to "conduct cross-disciplinary and inter-disciplinary work" (Irwin, Anuik, Kondzielewski, Meireles, Panescu, Stibbards, \& Stubbs, 2009, p. 2). Over five years, Inquiry "has been designed to help" students "to think from a cross-disciplinary perspective," with the expectation "to approach problems from more than one area of knowledge" (Irwin, Anuik, Kondzielewski, Meireles, Panescu, Stibbards, \& Stubbs, 2009, p. 2). For example, students may consider "a scientific and humanities direction" (Irwin, Anuik, Kondzielewski, Meireles, Panescu, Stibbards, \& Stubbs, 2009, p. 2). By Inquiry 1030, students move into "an interdisciplinary perspective ... combining ... knowledge from science, humanities, and social sciences to illuminate a given question or problem" (Irwin, Anuik, Kondzielewski, Meireles, Panescu, Stibbards, \& Stubbs, 2009, p. 2).

The team-taught Inquiry course has been an opportunity to animate the heart-brain connection in practice, but problems quickly surfaced with the expectations and assigned readings.

\section{The seven steps of inquiry.}

Inquiry 1010 is organized - in its first weeks - around steps outlined by Wade and Tavris (1990): ask questions, be willing to wonder, define the problem, examine the evidence, don't oversimplify it, analyze assumptions, avoid emotional reasoning, consider 
other interpretations, and tolerate uncertainty. A critical discussion of all of the steps is beyond the scope of this paper, but one step stood out for Jon as particularly problematic: avoid emotional reasoning. He believed that avoidance may be dangerously close to suppression of the heart and spirit in learning. From this belief, Jon translated a step in Inquiry 1010 into a pedagogical and practice-based opportunity to animate the heart and strive to connect it to the brain.

\section{Emotional reasoning.}

Wade and Tavris's (1990) justification of the need to avoid emotional reasoning on the surface seems logical through a western perspective: emotions may be understood as an impediment to reasoning. This logic, however, counters what we have been taught about emotional reasoning within Indigenous paradigms. Drawing from Goleman (1995) and Rann and Rann Arnott (2005), George (2010) identified how thoughts and feelings are interconnected, estimating that we

think 40,000 thoughts per day, and [the] majority are negative; [we] repeat 55$65 \%$ of these thoughts the next day; and over time these negative thoughts are manifested in negative feelings that impede the ability to retain relevant information, make sound judgments, and perform work effectively. (p. 24)

In this sense, it is not emotional reasoning that prohibits learning but an imbalance of negative thoughts that lead to specific emotions. As Kelly has stated, "Our prefrontal lobes enable meaning but when learning environments fail to ignite the passions of the learners, then the prefrontal lobes atrophy" (as cited in Anuik \& Battiste, 2008, p. 29). In other words, learners' prefrontal lobes make meaning when spiritual and emotional capacities are engaged alongside the mental capacities. As Cajete (2000) suggested, three foundational principles guide learning: the heart, face, and foundation. The heart is the passion that engages life purpose, the face is identity, and the foundation is the skills needed to put passion to work. The crucible of passion for George is learning in the moment, and teachers strive to facilitate the emotions and hearts of learners to join with the knowledge to evoke an outpouring of insights on a problem under consideration. George said, "I had to be there to learn in the moment, be there with my whole body. I had to learn as a being, rather than just learning as a practice of inheriting something and the language to talk about it" (as cited in Anuik \& Battiste, 2008, p. 16). In terms of application, after the weekly Friday lecture on emotional reasoning, Jon proposed to address emotional reasoning through a contemporary current event: the revelation in the media of politicians' mistakes in years past.

\section{Inquiry 1010 tutorial five: emotional reasoning.}

At the start of the tutorial, Jon presented the transcript of a conversation among political party staffers during an election. The full transcript of the conversation had been reproduced in a major newspaper in Canada and had triggered substantial criticism from politicians because of racist, sexist, homophobic, and anti-trade union remarks made by party workers and supporters. Two of those party workers and supporters are now in political office and representing Canadians. After the release of a video recording of the conversation and two public apologies, which Jon also presented to the class, the students 
were asked to reconcile the comments with the apologies and decide on actions that had the potential to affect negatively the career of one of the politicians. The students assumed the roles of party executive and backbenchers and they were challenged with the following exercise, addressing questions that Jon had debated with himself during the year and a half since the conversation had occurred:

1. Prepare an official statement to the major media outlets and non-governmental organizations with whom your government deals with officially:

a. What points do you need to emphasize in this statement?

b. Do you need to make amends and if so then what commitments do you need to make, financially and socially?

i. Keep your statement to less than one page single-spaced.

2. Decide if you need to take disciplinary action on your colleague (and justify your reasons) or, similarly, justify why no disciplinary action is needed

3. Prepare a press release to the media and non-governmental organizations with whom your government deals with officially.

This exercise obligated the students to deal with a challenge "in the moment" by developing the beginnings of resolution. They had to collaborate not only to take action but also to address their own perspectives on racism, sexism, homophobia, and labour unions.

The exercise parallels the practice of the talking circle described eloquently by Little Bear during the Banff Dialogue:

There were talking circles that helped people who needed assistance. In talking circles, everyone speaks to the concern, and the talk goes round and round until everybody has had their say, and there is no more to talk about. At the end of these rounds, however many rounds there may be, the spokesperson eventually comes out and says, "OK," and basically tells the person with the concern, "OK, you have heard the people speak; here is what they have said. Now take what they have said to resolve your problem, your concern." In other words, there is never any notion that says you have to do "ABC and D." Basically, the person with the concern will just sit there and listen and he never talks. (as cited in Anuik \& Battiste, 2008, p. 21)

Thus the student working groups needed at once to deal with remarks that triggered emotional responses and to decide on a course of action for their government, responsibilities that required the brain to collaborate with the heart. The instructor shared a primary source and questions that required the learners to co-construct a solution in collaboration with each other and the instructor. The instructor also had to respond to questions and provide factual information to help the learners, but the groups had to chart their path to resolution and, if necessary, reconciliation.

The students were invited to share their plans for action, mindful of consequences and the need to justify their decisions. They had to reflect, after hearing, through several rounds, their classmates speak. Emotional reasoning was deployed to deal with the comments made by the politicians, but the brain was also necessary in the partnership to chart a path toward resolution. They shared perspectives, generated knowledge, and took away insights to resolve a problem. Students were "readers, writers, researchers, presenters, collaborators, and educators" with "power in their lives" (Wiebe \& Guiney Yallop, 2010, p. 192) to suggest directions for political action, while at the same time gaining aware- 
ness of their own comprehension of racism, sexism, homophobia, and labour unions. The students better understood the vulnerabilities politicians face and their shared humanity with these individuals, given the opportunity to lead the Government of Canada. In this tutorial, learners' hearts and brains collaborated to address racism, sexism, homophobia, and labour unions through sharing perspectives on a problem: the comments and remarks that appeared in the transcript.

This section began with a lesson that seems logical: avoid emotional reasoning. The quotation based on George's (2010) review of the litearture seemed to suggest that emotions impede learning. However, emotions fuel passions that power hearts in scholarly work. If emotions overpower reason, or the brain overpowers the heart, humans are ineffective as learners in post-secondary education and in their pursuit of lifelong learning. Modern education stresses individualism and the pursuit of a singular, right answer that is the truth (Monture, 1995). However, education that has been informed by IK stresses collaborative pursuit to resolve problems in teams of learners whose hearts and brains have connected to address a problem through a format resembling Little Bear's story of the talking circles.

Jon's practice was to deliver a lecture on emotional reasoning that preceded the tutorial exercise. He started with what seemed, in the literature, to be logical: avoid emotional reasoning (Wade \& Tavris, 1990). He then oriented learners to the findings from George (2010) on emotional reasoning, identifying the erroneous conclusions that have, in Jon's opinion, misled learners to avoid emotional reasoning. He offered instead an alternative proposition, as stated by Kelly, that learning is a collaboration of the heart and the brain, and the heart is powered by emotions that energize passions. The result is the ability to reason, emotionally and mentally.

\section{EDUCATIONAL FOUNDATIONS 335: FIRST NATIONS AND CROSS-CULTURAL EDUCATION}

After completing her work with the ABLKC, Carmen taught courses for the Indian Teacher Education Program and the Department of Educational Foundations in the College of Education at the University of Saskatchewan. Although the knowledge she acquired through the ABLKC influenced how she taught all of her courses, she will describe in this section her experiences teaching anti-racism education courses to primarily white teacher candidates. The course, First Nations and Cross-Cultural Education, is not always well received by teacher candidates. Resistance to anti-racism and anti-oppressive education is well documented (LaDuke, 2009; Marx \& Pennington, 2003; St. Denis \& Schick, 2003), and numerous methods have been developed to address this resistance (Corkery, 2009; Fierros, 2009; Khanna \& Harris, 2009; Sleeter, Torres, \& Laughlin, 2004). Many of these methods, however, focus on increased mental capacities rather than the feelings that cause resistance. As Jon also articulates, through a western lens of education, avoiding resistance or emotional reasoning appears to benefit learners. IK provides a different perspective of pedagogy, a perspective that is based on holistic learning where one does not avoid natural feelings that may arise.

In this section, Carmen will acknowledge the interconnected Indigenous teachings that enhanced her pedagogical approach to anti-racism education and assisted many of her students through their feelings, which were at times traumatizing and caused resistance. 


\section{Learning blocks.}

To begin, Carmen found that understanding and applying the concept of "learning blocks" helped her to reconceptualize western notions of resistance. According to George,

in some cases, we got caught in the doubts and fears; those feelings have created blocks to learning, and we have at times forgotten our purpose. But our purpose is there and sometimes it is in these layers of oppression. We are taught to lead a life of balance; for me, that is the Creator's law. (as cited in Anuik \& Battiste, 2008, p. 31)

Cognitive imperialism affects everyone in different ways (Battiste, 2000). For white students, cognitive imperialism can produce an internalized and false sense of superiority and entitlement to land, resources, and power in society as privileged individuals. Predominantly, white students are taught to believe that their successes, and those of their families, are due to hard work alone; that is, meritocracy (St. Denis \& Schick, 2003). Antiracism education challenges and disrupts beliefs in meritocracy, with, as George (2010) has said, students being asked to peel away layers of cognitive oppression. This process of peeling away layers of oppressive ideologies assists students in comprehending how everyone is a product of colonialism, and it asks students to question who they are and why they may have experiences that others do not. These disruptions to notions of the self often cause fear that can manifest as anger, defensiveness, and guilt, and students may ultimately disengage from learning.

George makes this important point: "We have the emotional drop-out from the institutions before the physical drop-out; we need to dismantle fears if we are to engage spirit; fulfill their needs, not ours, but our learners' needs" (as cited in Anuik \& Battiste, 2008, p. 28). Although white students may not physically leave the institution because of antiracism education, many students mentally, emotionally, and spiritually drop out of antiracism courses (LaDuke, 2009; St. Denis \& Schick, 2003).

For Carmen, gaining insight about learning blocks created a shift in her pedagogy. She began to understand that although many white students resist anti-racism education in ways that maintain white-centered power and privilege, they also encounter real emotional, spiritual, and mental blocks that prevent learning. This awareness cultivated more empathy for students; consequently, more authentic and respectful relationships emerged, a central component of Indigenous conceptions of pedagogy. As Keith Goulet, Cree Métis, explains, "One of the central questions of pedagogy is how to build relationships; the building of the self in connection with others" (as cited in Anuik \& Battiste, 2008, p. 24). Within Indigenous paradigms, developing relational pedagogies through awareness of learning blocks can enable educators to nurture the learning spirits of students.

\section{Validating the learning spirit.}

Learning about the "learning spirit" and recognizing her own learning spirit as well as those of her students also affected Carmen's pedagogy and perceptions of resistance. As Musqua said, "We are born with an agenda - a spirit and a journey to carry out and put in the spirit consciousness" (as cited in Anuik \& Battiste, 2008, p. 13). Insight about the learning spirit provided courage to talk about racism in thoughtful and compassionate ways when facing hostile students and eased tension that arose from moments that 
seemed to "go wrong." For example, as a response to a student that interrupted a class to exclaim frustration and annoyance with the course content, a guest speaker was invited who ultimately affected the majority of students in positive ways. Unlike western conceptions of moments that "go wrong," which can be construed as "negative," Indigenous teachings about the learning spirit welcome these moments as gifts that generate creativity and growth, understood in a western conception as the teachable moment.

Recognizing that each student has a learning spirit also made it more possible to validate students who experienced learning blocks. Therefore, acknowledging and nurturing teacher candidates' learning spirits and assisting them to connect to their purpose became a central objective of anti-racism education. Validating each learner's learning spirit contributed immensely to Carmen's capacity to assist students through their learning blocks. Little Bear taught, "Little people need validation. We need a sense of nurture and for somebody to let us know that we are cared for" (as cited in Anuik and Battiste, 2008, p. 12).

A story about a young man who did not agree with the course content and was visibly agitated during class illustrates this point. Carmen recognized the student was troubled and asked to speak to him after class. When they met, he explained that his childhood experiences caused him to believe that First Nations peoples are inferior. Rather than argue with the student or dismiss his feelings as common, which she might have done in the past, the student's feelings were validated. She then suggested that his past experiences were blocking his ability to engage in the course and learn about oppression. This suggestion seemed to create a shift in the teacher candidate, and he actively began to read the assigned articles, listen intently, and participate in class discussions. Although the student has much more to learn about oppression, as we all do, Carmen believes that he made progress because he felt validated at the same time as his core beliefs were challenged.

For all anti-racism education instructors, and perhaps especially instructors that identify with Aboriginal peoples and other oppressed populations, it can be extremely difficult to validate students who openly express beliefs in human inferiority. However, as Little Bear said,

the approach is to be a catalyst for the students' learning, but the greatest challenge for teachers is seeing, validating the learner. How do I validate that which is human in this person in an individual way, in a unique way? And that is a different capacity than that which we have been trained in our education. (as cited in Anuik \& Battiste, 2008, pp. 14-15)

When validated, students are more able to move through paralyzing emotions such as anger, defensiveness, grief, guilt, and denial to enable empowering feelings such as empathy, hope, and a sense of responsibility. George taught, "People need to have acceptance, especially if they don't have acceptance within themselves" (as cited in Anuik \& Battiste, 2008, p. 14). Acceptance and validation of students can nourish the learning spirit in ways that invoke holistic learning and can transform denial into wisdom.

\section{Holistic learning.}

Although traditionally "much of the education that we received came through this sensing of the heart; this particular kind of thinking"' (Kelly as cited in Anuik \& Battiste, 2008, 
p. 23), most contemporary teachers and teacher candidates have been trained in western education and, therefore, want to practise anti-racism education through mental capacities only. Students also come into the classroom conditioned to learn mentally and to avoid emotional reactions. In anti-racism education, however, learning cannot happen if emotions are left out of the process. As a result of learning about Indigenous conceptions of holistic education and the obvious resistance students had to expressing their feelings, Carmen created several assignments to address this tension. One assignment, worth 10 per cent of the final grade in the course, asked students to write 10 entries that documented their feelings about the course readings and discussions. Each entry received $1 \%$ toward the final grade, regardless of what was written, to validate students and foster holistic learning. This assignment enabled students to express anger, frustrations, and struggles, and to know that these feelings were valued by receiving a grade. Many of the students' entries were stories that connected the course theory to personal experiences and feelings.

Elders and speakers at the Banff Dialogue spoke about the importance of stories in Indigenous pedagogy. Laara Fitznor of the Nisichawayasihk Cree Nation explained, "When I teach, I ask all students to come with a voice; to tell their stories. I work with the heart and with the spirit so that my students can read other people's works and develop their own passions" (as cited in Anuik \& Battiste, 2008, p. 23). Stories are foundational to holistic education and play a central role in anti-racism education and critical race theory (LadsonBillings \& Tate, 1995). Stories can connect theory to life - both to understand life and to imagine life differently. For example, although Carmen is of Métis and Chinese ancestry, she also has Norwegian ancestry, blue eyes, and white privilege. Sharing her story of how she, too, has benefited from white privilege enabled many students to understand how they also have unearned privileges. Stories can nurture empathy and connectedness and humanize those who are objectified through sterile facts presented in texts. Stories can give others the courage and empowerment to share and honour personal experiences and voice. In anti-racism education, students are asked to remember personal, family, and community histories and to re-examine the stories that shape beliefs about their identities through a new lens. In many ways, this process is similar to what Kelly described:

When we put consciousness into a story, it becomes like an experience, and the meaning making follows because the knowing drops into us at different times of our lives. We recognize the spirit of the stories throughout our life; stories help to create a living knowing. (as cited in Anuik \& Battiste, 2008, p. 18)

Students, guest speakers, individuals in documentaries, authors of the assigned papers, and Carmen shared stories throughout the term. Stories ignited within students a passion to speak out against racism and helped students who struggled with the course content to know they were not alone. Stories gave teacher candidates hope that education can create change and work to counter the oppression that Aboriginal peoples and all oppressed populations continue to experience.

Too often, the focus of Aboriginal education is on integration of Aboriginal content rather than decolonizing pedagogy and practice. Carmen believes she is beginning to decolonize her teaching practice as a result of the Indigenous conceptions of pedagogy learned through her work with the ABLKC. Her comprehension and application of rela- 
tional, pedagogical principles such as learning blocks, the learning spirit, student validation, holistic learning, and stories also affected many of her teacher candidates. Unlike former years, she stayed engaged with her classes at times when in the past she might have disengaged because of what she perceived as student anger, resentment, and resistance. She was also able to teach in a more compassionate, relational, and holistic way, which led to increased student academic success and personal commitments to anti-racism, anti-oppressive, and Aboriginal education, for both the students and the instructor.

\section{LESSONS}

We share the philosophy that learning must enable the heart, brain, body, and spirit to collaborate to evoke an outpouring of critical thought and personal transformation. Throughout the courses we taught, we emphasized the centrality of the heart and brain collaboration to learning and built an atmosphere that enabled learners to bring forth their ability to inquire. Our desire to animate the learning spirit in practice enabled students to question power and privilege and white supremacy in modern society; to challenge cognitive imperialism and work toward processes of decolonization. There was a shared commitment to building "a safety net by which students can take greater risks in their learning and discovery of identity" (Wiebe \& Guiney Yallop, 2010, p. 186). We have addressed our own fears about our abilities as teachers and understand that teaching a course is a shared endeavour with students who are given the chance to invest in the direction of their own learning journeys.

\section{CONCLUSION}

This paper, the result of consultation with contributors to the Banff Dialogue, is the outcome of a pedagogy generated by our engagement with a project in Aboriginal lifelong learning. It charts a path on the infusion of IK into post-secondary educators' pedagogy and practices and builds on existing critiques of the absence of IK in teachers' practices. We are in part addressing calls among policy-makers in provincial and territorial ministries of education to move IK from "the margins to the mainstream" (Kovach, 2010, p. 8) and to centre IK in teacher education. To do so, teacher educators and candidates must join Indigenous knowledge with modern instruction or achieve, as Kovach argued, "IKFriendly pedagogy" (2010, p. 4).

Overall, this paper is part of an ongoing project to animate Indigenous paradigms of learning in practice with learners in a diversity of formal, informal, and non-formal learning contexts. It represents a journey for us, both of whom have been trained in Canadian public schools. Our practices came as a result of reflections on our work related to the learning spirit, and they are indicative of the potential to affect all courses, subjects, and grade levels throughout the formal education system. It is clear that IK can strengthen teachers' pedagogies regardless of the cultural or racial identities of the teachers or students.

This narrative is now yours. We hope that you are able to build on the insights and practices shared with you.* 


\section{REFERENCES}

Adams, H. (1972). The outsiders: An educational survey of Métis and non-Treaty Indians of Saskatchewan. Saskatoon: Métis Society of Saskatchewan.

Anuik, J. (2010). "In from the margins": Government of Saskatchewan policies to support Métis learning, 1969-1979. Canadian Journal of Native Education, 32, 83-99.

Anuik, J., \& Battiste, M. (2008). Animating the spirit in Aboriginal lifelong learning: Report of the May, 2007 Banff Dialogue for Animation Theme Bundle 2: Comprehending and Nourishing the Learning Spirit. Unpublished report for the Aboriginal Learning Knowledge Centre, in partnership with the Canadian Council on Learning.

Anuik, J., Battiste, M., \& George, N. (2008). Comprehending and nourishing the learning spirit: A final summary report on the literature reviews conducted by Animation Theme Bundle 2. A report prepared for the Aboriginal Learning Knowledge Centre, in partnership with the Canadian Council on Learning.

Ball, J., \& Pence, A. (2006). Supporting Indigenous children's development. Vancouver: University of British Columbia Press.

Battiste, M. (1986). Mi'kmaq literacy and cognitive assimilation. In J. Barman, Y. Hébert, \& D. McCaskill (Eds.), Indian education in Canada: Volume 1: The legacy (pp. 23-44). Nakoda Institute Occasional Papers. Vancouver: University of British Columbia Press.

Battiste, M. (2000). Maintaining Aboriginal identity, language and culture in modern society. In M. Battiste (Ed.), Reclaiming Indigenous voice and vision (pp. 192-208). Vancouver: University of British Columbia Press.

Battiste, M. (2005). Post-colonial remedies for protecting Indigenous Knowledge. In P. Tripp \& L. Muzzin (Eds.), Teaching as activism: Equity meets environmentalism (pp. 224-232). Kingston: McGill-Queen's University Press.

Battiste, M. (2007). Literature review synopsis of programs and practices that nourish the learning spirit. Unpublished paper for the Aboriginal Learning Knowledge Centre, in partnership with the Canadian Council on Learning.

Battiste, M., Anuik, J., \& Gillies, C. (2009). Nourishing the learning spirit: Emerging promising practices for teaching and lifelong learning. Presentation for the Canadian Society for the Study of Education 2009 Conference: Learning Spaces, Places and Connections. Carleton University, Ottawa, ON, May, 2009.

Battiste, M., George, N., \& Anuik, J. (2009). Nourishing the learning spirit: A review of literature and promising practices. Unpublished paper for the Canadian Society for the Study of Education 2009 Conference: Learning Spaces, Places and Connections. Carleton University, Ottawa, ON, May, 2009.

Battiste, M., \& Henderson, J. S. Y. (2008). Naturalizing Indigenous Knowledge in education: A synthesis paper. Unpublished paper for the World Indigenous Peoples Conference on Education, Melbourne, Australia, December, 2008.

Bishop, A. (1994). Becoming an ally: Breaking the cycle of oppression. Halifax: Fernwood. 
Cajete, G. (2000). The Pueblo metaphor of Indigenous education. In M. Battiste (Ed.), Reclaiming Indigenous voice and vision (pp. 181-191). Vancouver: University of British Columbia Press.

Canadian Council on Learning. (n.d.). About CCL. Retrieved from http://www.cclcca.ca/CCL/AboutCCL/?Language $=\mathrm{EN}$

Canadian Council on Learning (2006). Animation theme bundle 2: Comprehending and nourishing the learning spirit. Retrieved from http://www.ccl-cca.ca/CCL/AboutCCL/ KnowledgeCentres/AboriginalLearning/Themes/AnimationThemeBundle2.htm

Corkery, C. (2009). Rhetoric of race: Critical pedagogy without resistance. Teaching English in the Two Year College, 36(3), 244-256.

Curtis, B. (1987). Building the educational state: Canada West, 1836-1871. London: Althouse Press.

Curtis, B. (1992). True government by choice men? Inspection, education, and state formation in Canada West. Toronto: University of Toronto Press.

Fierros, E. G. (2009). Using performance ethnography to confront issues of privilege, race, and institutional racism: An account of an arts-based teacher education project. Multicultural Perspectives, 11(1), 3-11.

Francis, D. (1997). National dreams: Myth, memory and Canadian history. Vancouver: Arsenal Pulp Press.

Freire, P. (1998). Pedagogy of the heart. New York: Continuum.

George, N. (2010). Aboriginal adult literacy: Nourishing their learning spirits. Literature Review for the Aboriginal Learning Knowledge Centre, in partnership with the Canadian Council on Learning. Retrieved from http://www.ccl-cca.ca/pdfs/ablkc/ NourishingSpirits_LitReview_en.pdf

Gere, A., Buehler, J., Dallavis, C., \& Haviland, V. (2009). A visibility project: Learning to see how preservice teachers take up culturally responsive pedagogy. American Educational Research Journal, 46(3), 816-852.

Goleman, D. (1995). Emotional intelligence: Why it can matter more than IQ. New York: Bantam Books.

Henderson, J. S. Y. (Sákéj). (2000). Ayukpuchi: Empowering Aboriginal thought. In M. Battiste (Ed.), Reclaiming Indigenous voice and vision (pp. 248-278). Vancouver: University of British Columbia Press.

Hill, D. L. (1999). Holistic learning: A model of education based on Aboriginal cultural philosophy. Unpublished master's thesis, Saint Francis Xavier University, Antigonish, Nova Scotia, Canada.

Irwin, D., Anuik, J., Kondzielewski, T., Meireles, H., Panescu, R., Stibbards, A., \& Stubbs, T. (2009). Inquiry 1010: Foundations of Inquiry, Fall 2009.

Khanna, N., \& Harris, C. (2009). Teaching race as a social construction: Two interactive class exercises. Teaching Sociology, 37(4), 369-378. 
Knight, D. (2007). The seven fires: Teachings of the Bear Clan as told by Dr. Danny Musqua: Knowledge of human growth and learning practiced in the old world of the Nacowaninawuk (Saulteaux): A guide to health and wellbeing in the new world. Prince Albert: Many Worlds.

Kovach, M. (2010). Toward an IK-friendly pedagogy in mainstream classrooms: A single site pilot study of non Indigenous faculty perspectives on integrating Indigenous Knowledges into their course instruction. Unpublished technical report, College of Education, University of Saskatchewan, Saskatoon, Saskatchewan, Canada.

Ladson-Billings, G., \& Tate, W. (1995). Toward a critical race theory of education. Teachers College Record, 97(1), 47-68.

LaDuke, A. (2009). Resistance and renegotiation: Preservice teacher interactions with and reactions to multicultural education course content. Multicultural Education, 16(3), 37-44.

Malreddy, P. K. (2009). Seeing ourselves in the mirror: Giving life to learning. Report of the Aboriginal Learning Knowledge Centre's Second National Conference, in partnership with the First Nations Education Steering Committee. Retrieved from http:// www.ccl-cca.ca/pdfs/ablkc/ABLKCConf2008_Mar302009.pdf

Marx, S., \& Pennington, J. (2003). Pedagogies of critical race theory: Experimentations with white preservice teachers. International Journal of Qualitative Studies in Education, 16(1), 91-110.

Monture, P. (1995). Thunder in my soul: A Mohawk woman speaks. Halifax: Fernwood.

Rann, M. C., \& Rann Arnott, E. (2005). Shortcut to a miracle, how to change your consciousness and transform your life. Santa Monica: Jeffers Press.

St. Denis, V., \& Schick, C. (2003). What makes anti-racist pedagogy in teacher education difficult? Three popular ideological assumptions. Alberta Journal of Educational Research, 49(1), 55-69.

Sleeter, C., Torres, M., \& Laughlin, P. (2004). Scaffolding conscientization through inquiry in teacher education. Teacher Education Quarterly, 31(1), 81-96.

Smith, L. T. (1999). Decolonizing methodologies: Research and Indigenous peoples. London: Zed Books.

Wade, C., \& Tavris, C. (1990). Thinking critically and creatively. Skeptical Inquirer, 14, 372-377.

Wiebe, S., \& Guiney Yallop, J. J. (2010). Ways of being in teaching: Conversing paths to meaning. Canadian Journal of Education, 33(1), 177-198.

Willinsky, J. (1998). Learning to divide the world: Education at empire's end. Minneapolis: University of Minnesota Press. 


\section{CONTACT INFORMATION}

Jonathan Anuik

Department of Educational Policy Studies

Faculty of Education

University of Alberta

Edmonton AB T6G 2G5 Canada

anuik@ualberta.ca

Jonathan Anuik was an Assistant Professor in the Departments of History and Interdisciplinary Studies, Lakehead University, Orillia, Ontario, and is now an Assistant Professor in the Department of Educational Policy Studies at the University of Alberta in Edmonton, Alberta. He teaches courses on concepts of childhood, educational research, and the history of Indigenous education, and he researches Métis education in Saskatchewan after the Northwest Resistance of 1885 . His research interests also include spirituality and learning, both historical and contemporary; Métis education in Ontario; interdisciplinary, community-based research; teaching and learning; and children's rights. The Canadian Plains Research Center at the University of Regina published his book, First in Canada: An Aboriginal Book of Days, which has been shortlisted for the 2011 Saskatchewan Book Awards in the First Peoples' Publishing Award and the Award for Publishing categories.

Carmen Gillies is a PhD Candidate in the Department of Educational Foundations at the University of Saskatchewan. She is a senior research assistant with the Canadian Prevention Science Cluster at the Aboriginal Education Research Centre and an Educational Foundations sessional lecturer. Carmen's research interests include anti-racist, anti-colonial education; mixed raced studies; critical race theory; and Indigenous education.

\section{ACKNOWLEDGEMENTS}

Thank you to Dr. Marie Battiste for her supervision of and guidance on our work for the ABLKC. We are grateful that the ABLKC, in partnership with the CCL, financially supported our research activities from 2006 to 2009. We also thank the participants in the May 2007 Banff Dialogue for their outstanding contributions on spirituality and Aboriginal lifelong learning. 